

Global Journals Inc.

sing

\title{
Human Trafficking and Prostitution in Mozambique: The Mualy, Amalapos and the Police
}

By Judil Virgílio Marrupe, Jaime Luiz Cunha de Souza \& Maria José da Silva Aquino Teisserenc

Federal University of Pará

Abstract- This article discusses processes of human trafficking for prostitution in Mozambique. It begins by situating the African continent within the dynamics of globalization processes, associating human trafficking with poverty and discussing it as a profitable illegal activity conducted on a global scale. It continues by presenting the historical factors and economic constraints that put the Mozambican population in a vulnerable situation in relation to human trafficking and prostitution. The article then examines how the perceptions of police regarding women trafficked for prostitution are affected by the local institution referred to as Mualy. Quantitative data come from the Statistic Brain Research Institute, compiled from the following reports: UNAIDS, World Bank and Demographic Dividend for the period of 2010 to 2017. Qualitative data were collected through ten interviews with the Provincial Command Squads of the Police of the Mozambique Republic (PRM) of Nampula, a city located in northern Mozambique. Results show that cultural factors interfere with how Mozambican police perceive human trafficking for prostitution and that such interferences undermine authorities' strategies to combat this type of crime.

Keywords: human trafficking; prostitution; mualy; amalapo; police.

GJHSS-C Classification: FOR Code: 160899



Strictly as per the compliance and regulations of:

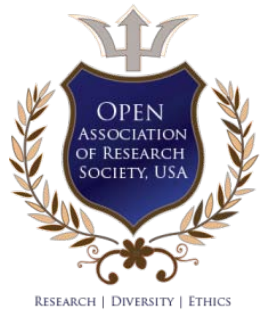

(C) 2019. Judil Virgílio Marrupe, Jaime Luiz Cunha de Souza \& Maria José da Silva Aquino Teisserenc. This is a research/review paper, distributed under the terms of the Creative Commons Attribution-Noncommercial 3.0 Unported License http://creativecommons.org/licenses/by-nc/3.0/), permitting all non-commercial use, distribution, and reproduction in any medium, provided the original work is properly cited. 


\title{
Human Trafficking and Prostitution in Mozambique: The Mualy, Amalapos and the Police
}

\author{
Judil Virgílio Marrupe ${ }^{\alpha}$, Jaime Luiz Cunha de Souza ${ }^{\circ} \&$ Maria José da Silva Aquino Teisserenc ${ }^{\circ}$
}

\begin{abstract}
This article discusses processes of human trafficking for prostitution in Mozambique. It begins by situating the African continent within the dynamics of globalization processes, associating human trafficking with poverty and discussing it as a profitable illegal activity conducted on a global scale. It continues by presenting the historical factors and economic constraints that put the Mozambican population in a vulnerable situation in relation to human trafficking and prostitution. The article then examines how the perceptions of police regarding women trafficked for prostitution are affected by the local institution referred to as Mualy. Quantitative data come from the Statistic Brain Research Institute, compiled from the following reports: UNAIDS, World Bank and Demographic Dividend for the period of 2010 to 2017. Qualitative data were collected through ten interviews with the Provincial Command Squads of the Police of the Mozambique Republic (PRM) of Nampula, a city located in northern Mozambique. Results show that cultural factors interfere with how Mozambican police perceive human trafficking for prostitution and that such interferences undermine authorities' strategies to combat this type of crime.
\end{abstract}

Keywords: human trafficking; prostitution; mualy; amalapo; police.

\section{InTRODUCTION}

$\mathrm{H}$ uman trafficking, or sale, is considered a violation of human rights by various international conventions and constitutes a criminal activity with transnational implications. It is, further, one of the most lucrative practices in the world. Networks constantly develop new routes and recruitment systems that attract victims from the peripheries of medium-sized and large cities and rural areas of poor and underdeveloped nations. Conditions of poverty are readily found in African countries, which have experienced war, social inequalities, poverty, government corruption, and above all, continue to be economically dependent on colonizing countries (Dias, Lucio and Coelho, 2015). Together these characteristics create a situation of social vulnerability, where individuals are more easily enticed by the possibility of

Author $\alpha$ : Inspector of the Mozambican Police, Masters in Sociology, Federal University of Pará - Brazil. e-mail: judil.marrupe@gmail.com

Author o: Federal University of Pará - Brazil, Doctorate in Social Sciences, Professor of the Graduate Program in Public Security, Federal University of Pará. e-mail: jaimecunha@ufpa.br

Author p: Federal University of Pará - Brazil, Doctorate in Sociology. Professor, Graduate Program in Sociology and Anthropology. illegally immigrating to other African countries or to Europe. Criminals involved in human trafficking networks take advantage of vulnerable people, who at first intend to immigrate illegally, but are forced into sexual exploitation and forced labor.

Figures on human trafficking in Africa draw attention for their magnitude. However, the focus of this article is on the particularities of this phenomena in Mozambique, a country of Portuguese colonization located on the southwest coast of the African continent, surrounded by the Indian Ocean, in front of Madagascar. In 1975, after 10 years of war, Mozambique gained its independence from Portugal. Two years after independence, a civil war took hold of the country and Mozambique remained in this state until the early 1990s. More than three decades of war were extremely destructive, especially socially and politically; and, as is most relevant to our topic, have meant that institutional and political organizational efforts have not been sufficient to ensure that the Mozambican government satisfactorily enforces the requirements of the Trafficking Victims Protection Act (TVPA). While some incipient government efforts have been made to comply with this law, its effects are not yet clearly visible.

According the Statistic Brain Research Institute 2018 crime report, which presents data on people trafficked for prostitution in Africa, trafficking routes traverse Mozambique and the country is, to a lesser degree, a destination for men, women, and children submitted to forced labor and sexual exploitation. Women from Mozambique are exploited as prostitutes in bars, roadside clubs, restaurants in frontier cities, and night stops along Mozambique's southern transport corridor towards South Africa. According to the report, child prostitution is prevalent in the cities of Maputo, Namula and Beira, and is also increasing in the cities of Chimoio and Nacala, both known for high population mobility and for hosting large numbers of truck drivers. Individual prostitution is not prohibited in Mozambique, but organized activities, such as running brothels, are illegal since such activities are not regulated.

To product this article we analyzed quantitative data provided by the Statistic Brain Research Institute, which are organized in the joint reports of the United Nations Programme on HIV and AIDS (UNAIDS) and the World Bank (Demographic Dividend) and refer to the 
period of 2010 to 2017. Qualitative data on police officers' perceptions on human trafficking for prostitution in Mozambique were collected through ten semistructured interviews conducted with the commanders of the Provincial Command Squads of the Police of the Mozambique Republic (PRM) in Nampula, located in northern Mozambique. All interviewed police officers have more than 15 years of experience with the PRM. These officers were chosen based on their time in service and the fact that they belong to the Macua, the ethnic group of many victims. Thus, they share cultural values and practices and may have a particular vision regarding people trafficked for prostitution. In some cases, the people interviewed denied the existence of trafficking or attributed the responsibility of the crime to the victims themselves.

\section{Human Trafficking: The African Dimension of a Global Problem}

Human trafficking for prostitution in Africa is considered one of the undesirable consequences of communication and transportation technologies development and the circulation of goods related global capitalist expansion. Even though human trafficking has been present in Western history for a long time (Bullough and Bullough, 1987; Cohen, 1992), its contemporary form as a highly lucrative activity was boosted through legal and illegal international immigration (Ausserer, 2011; Carling, 2007; Thapisa, 2000).

Human trafficking is among one of the most lucrative illicit activities in the world. It has an especially concerning impact on the African continent due to the disadvantageous way in which global technological, social, and economic transformations are experienced by these countries. African nations suffer from grave structural deficiencies exacerbated by social inequalities and political instabilities, keeping them in a chronic state of poverty. For Bank (2010) and Aderinto (2015), the recent technological conquests related to the most recent phase of globalization, including the development of information and communication technologies (ICT), have had both negative and positive effects. On the one hand, they made it possible for citizens and public institutions to connect to other cultures; on the other hand, they failed to increase, and in some cases diminished, work opportunities. One of the consequences of the ambiguities of African globalization is that the productive gains of technological investments did not bring significant benefits to local populations, especially of poorer countries plagued by structural unemployment. These investments thus exacerbated existing conditions of social exclusion. According to Raimi (2012) and Bank (2010), the formation of regional economic blocks, such as Economic Community of West African States,
(ECOWAS), Southern Africa Development Community (SADC), and the New Alliance for African Development and the African Union (UA), encouraged the implementation of free trade and border liberalization. These changes occurred in the absence of policies protecting and promoting human rights. The authors clarify that the instability and continuing fragility of African national states creates fertile grounds for the expansion of illicit activities, including human trafficking.

With ECOWAS people were able to circulate more freely across borders, which resulted in the weakening of already precarious state measures controlling the flow of people, goods, and services within signatory countries. Geopolitical restructuring facilitated organized crime operations across borders because at the time of this re-organization African states were primarily concerned with economic problems delegating the responsibility of controlling crime and human rights violations to local governments (Raimi, 2012).

Economic fragilities and technological possibilities spurred sex commerce, which came to play an important role in the survival strategies of young Africans (Lagunas, 2010). The recent increase in disorderly urbanization the transnational dimension of the tourist industry considerably stimulated activities related to trafficking of women for prostitution - such that trafficking of Africans to Europe and within Africa now have a significant economic and social impact. Carling (2007) demonstrated that some European countries appear quite attractive to young Africans who consider migration a means to escape war and economic difficulties in their countries of origin. Young people's desire to migrate illegally to Europe stimulated the formation of criminal groups who consider human trafficking an excellent opportunity to leverage profits. Some illegal immigrants reach destinations inside the African continent; their mobility is mediated by a network of traffickers responding to the demand for illegal workers to work as domestic servants and as miners in South African mines (Adepoju, 2000; Raime, 2012). Those involved in human trafficking partner with criminals from old and already consolidated contraband networks; through the use of these structures, they make human trafficking activities viable.

According to Adepoju (2000), 95\% of illegal African immigrants arrived in Europe through the intermediation of traffickers. As immigrants without regular documentation they are more vulnerable to the enticement and grooming of actors involved in sexual exploitation networks. The journey to Europe is long and dangerous and involves staying for a relatively long time in North Africa, awaiting the opportunity to cross the Mediterranean Sea. As such, some women who exit sub-Saharan African countries wait months or even years to conclude their journeys to Europe. Barros et al. (2002) explains that a portion of migrants remain in 
North African cities to work and save money to continue their trips. However, an increasing number of migrants are unable to go further and wind up establishing themselves in these cities, living and working precariously. For women, this state of invulnerability could eventually lead them to prostitution.
Table 1 shows the income levels associated with forced labor in its different modalities and the number of people victimized by criminal networks on the African continent.

Table 1: Data on Forced Labor in Africa (2010-2017)

\begin{tabular}{l|c}
\hline \multicolumn{1}{c|}{ Annual profits from forced labor } & US $\$ 13,100,000,000$ \\
\hline Average profits per victim of forced labor & US\$ $\$, 900$ \\
\hline Number of forced labor victims at any given time & 3.500 .000 \\
\hline Percentage of victims used for sexual exploitation & $52 \%$ \\
\hline Percentage of victims used for forced labor & $40 \%$ \\
\hline Percentage of victims used for other types of exploitation & $8 \%$ \\
\hline
\end{tabular}

Source: Statistic Brain Research Institute, 2018

We observe here that the largest percentage of victims were trafficked for sexual exploitation; however, a significant percentage of people are also exploited as forced laborers. According to 2016 data from the International Labor Organization (ILO), many girls, women, and even young men who were victims of human trafficking had previously experienced some form of physical and sexual violence in their lifetimes or were neglected at home. Violence was cited as one of the reasons that these victims had wanted to take their chances and migrate illegally. Connelly and Sanders (2016), Sanders, O'Neill and Pitcher (2017) show that migration and eventual prostitution have become a perceived means of social mobility and satisfying basic needs. Young Africans may also decide to immigrate illegally to help families in their origin countries who live in extremely difficult economic conditions. Within this context, prostitution presents itself as an activity that allows for daily survival.

In sub-Saharan Africa, prostitution is associated with highway transportation corridors, which became extremely well-traveled with the opening of borders for the circulation of goods. With these shifts, clusters of road workers emerged, mainly drivers, along with the recruitment and exploitation of youth and children. Pateman (2016) shows that in urban environments, recruitment into prostitution is related to sexual tourism and human trafficking. This author states that sexual exploitation is part of an obscure yet fundamental part of the recreation industry - for which prostitution is one of the most lucrative illicit products. Bales and Friman (2002) commented that in most countries where tourism strongly contributes to the economy, consolidated structures that include prostitution networks exist and include children and adolescents of both sexes.

In addition to the macrostructural factors that make prostitution viable, the appeal of consumption also plays a role in this phenomenon. Traditional African communities are increasingly being co-opted by the consumerist logic that accompanies urbanization and its global connections (Roby, 2005). According to this author, many families are enticed by goods, money and promises of educational opportunities. These promises, which for many begin with illegal immigration, are likely to end in sexual exploitation and prostitution.

\section{ili. Trafficking And Prostitution in}

\section{MozambiQue}

Human trafficking for prostitution in Mozambique is historically linked to the processes of human occupation and African colonization by European countries and extends beyond these countries' struggles for independence into the 20th century. According to Muianga (2009), during much of the colonial period, a system dedicated to recruiting prostitutes from countries such as Portugal, Italy and France to meet the demand of a mostly white Portuguese clientele operated in the city of Lourenço Marques (now Maputo city, capital from Mozambique). The period of European colonization, which lasted until 1975, imposed a domination over the diverse cultures in the territory that today constitutes Mozambique. In particular, colonial rule was marked by strict work regulations and rigid family and marital structures, upheld by the assumption that Europe had, relative to African nations, more civilized cultures and traditions (Alexandre, 2008). European values and constraints dictated by Christian doctrines played an important role in domination exercises (Langa, 1984; Lopes, 1972; Pereira, 2000). The imposition of European cultural standards on Mozambicans was accompanied by a growing demand for white prostitutes of European origin. Subsequently, after independence, the demand for young Mozambicans for this purpose also emerged (Alós, 2011; Pinho, 2015).

Muianga (2009) explains that during the colonial period, demand for European sex workers in the city of Lourenço Marques was related to the highly racialized Mozambican society, where native Mozambicans were relegated to a lower status on the social hierarchy. Slowly, Mozambicans were integrated into the prostitution market due to new laws in European 
countries seeking to stop the flow of white women destined to the African colonies to be prostitutes. At the same time, young Mozambicans increasingly came to view prostitution as means to achieve social mobility and meet basic personal and family needs (Aderinto, 2015; Tamale, 2006).

Mozambique had two long wars, a war fought for independence from the Portuguese, followed by a civil war. The first began in 1964 and ended in 1975 with independence from the Portuguese and the coming to power of the guerilla group, the National Liberation Front of Mozambique National Liberation Front (Frente Nacional de Libertação de Moçambique - Frelimo). The second war, as previously mentioned above, began in 1977 and ended in 1992. During the second war period, government forces formed on the basis of Frelimo's cadre were opposed by the Mozambican National Resistance Movement - Movimento de Resistência Nacional de Moçambique - Renamo) that initially emerged as a right-wing guerrilla group created to counter official socialist-oriented forces (Collier e Hoeffler, 1998; Collier and Sambanis, 2005).

When Frelimo was in power, they implemented a policy called "Operação Produção" (Production Operation), which consisted of barring rural people from moving to urban zones. The Frelimo government saw these rural-urban flows as responsible for the great numbers of people concentrated in urban areas, forming groups of beggars, prostitutes, unemployed and criminal masses. In addition to curbing the countrycity flows, the program sought to relocate the poor to forested regions in northern Mozambique so that they could become "productive," producing foods for selfsustenance. This strategy considerably decreased prostitution in urban areas (Hamela, 2011; Muianga, 2009).

Although some efforts were made by the Frelimo socialist government towards gender equally in the domestic sphere, traditional notions of women being responsible for managing the family and home and restrictions on expressions of female sexual freedom remained (Arnfred, 2002). The Fremlimo and Catholic Church's perspectives on this point were quite similar; both disapproved of women who engaged in sexual relations for commercial purposes or who expressed their sexuality in a way that diverged from traditionally accepted norms. In this way, the paradigm of women in charge of the home and responsible for her family, but passive in relation to men, was upheld.

After the civil war and the country's return to the market economy, a series of measures to expunge what was remaining of the colonial period were established. Mozambique's government, extremely fragile after years of war, attempted to recover its inflicted economy; yet, authorities found this an impossible task using its own resources alone. At this time, the government resorted to the international financial system, which according to
Leite (1999), opposed very strict adjustments on the country, including privatizations of state firms, which up to the reforms had been important job sources in Mozambique. As a result, unemployment increased in an economy where jobs were already scarce due to the devastating effects of war on the country's productive system. Structural adjustment and its effects hit the poorest sectors of the population the hardest; and the poorest and most most marginalized people had little wherewithal to adapt to the newly imposed economic order.

Families' daily lives were also greatly affected. The social status of men and women, their roles, and society's expectations of both sexes were significantly redefined. For poor men, the negative consequences of losing their ability to provide for their families was exacerbated by changes in young women's expectations for futures and their social condition. According to Meneses (2008), the possibility of moving from rural areas to urban areas to find work, to study, or to meet a prospective partner who could provide a better life was increasingly appealing to young women. The opening of the economy resulted in the formation of an incipient middle class; individuals of this group were able to take advantage of the new economic moment of the country. Men also arrived from Europe and other parts of the world to work in the multinational companies. These men were considered "rich" compared to locals with lower purchasing power. Young poor men, principally from rural areas and the cities' peripheries, remained in an extremely disadvantaged position in relation to these groups and became less attractive to young women as potential partners (Fry, 2000).

With the effects of economic adjustments imposed by the International Monetary Fund (IMF) quickly worsening, and the government mainly concerned with this problem, poor communities had difficulty developing and implementing survival strategies. With few possibilities, prostitution and the networks supporting sex work strengthened and managed to recruit a growing number of young people, especially females, into their workings. Groes-Green (2011) states that at this moment, a cultural conflict settled upon Mozambican society. Specifically, we observe a divergence between those once inserted into prostitution, use the erotic and sexual knowledge transmitted by older female relatives and healers as a way to overcome economic fragilities, and those who saw this strategy as a violation and misuse of traditional teachings and values.

Despite these tensions, a lucrative sex industry formed in Maputo with direct links to human trafficking. At the same time, the recruitment of young people for labor exploitation and prostitution was being adjusted to smuggling and drug trafficking networks already in operation throughout sub-Saharan Africa. According to 
Muianga (2009), the young Mozambicans recruited to work in mines, mainly migrated to South Africa - where important gold, graphite, diamond and other ores of high international value are found. Feliciano (1998) shows that parallel to these movements, Mozambicans have also travelled to work on large plantations.

Studies conducted by the United Nations International Children's Emergency Fund (UNICEF,
2012) show that in addition to migrating to work in mines and on plantations, there is an increase in flows of Mozambican children and women for sexual exploitation.

Data on Figure 1 show the annual averages of migration related to human trafficking both into and out of Mozambique.



Source: Statistic Brain Research Institute, 2018.

Figure 1: Data on human trafficking and forced labor in Mozambique (2010-2017)

The Mozambican government began to show interest in issues human trafficking and prostitution in the mid-1990s. The country's reconstruction and the degree of political stability achieved after the civil war influenced governmental attitudes in this sense. Concern with human trafficking as a political agenda was demonstrated by the participation of Mozambican representatives at the World Congress against the Commercial Sexual Exploitation of Children held in
Stockholm in 1996. However, the protagonists came from international organizations with representation in Mozambique and civil society - from which the primary denouncements against criminal networks and ineffective government actions to curb their activities originated.

Table 2 demonstrates the financial resources involved in the different modalities that compose these criminal activities in Mozambique.

Table 2: Data on forced labor in Mozambique (2010-2017)

\begin{tabular}{l|c}
\hline Annual profit from forced labor & US\$175,000,000 \\
\hline Average profit per forced labor victim & US\$4,200 \\
\hline Number of forced labor victims at any given time & 29.000 \\
\hline Percentage of victims used for sexual exploitation & $39 \%$ \\
\hline Percentage of victims used for forced labor & $6 \%$ \\
\hline Percentage of victims used for other types of exploration & $6 \%$ \\
\hline Percentage of people involved in illegal migratory processes not destined for forced labor & $9 \%$ \\
\hline
\end{tabular}

Source: Statistic Brain Research Institute, 2018.

As a result of their situation of greater vulnerability, women are the primary victims of both human trafficking and sexual exploitation. Women are more accessible to the criminal networks who prey upon their desires for a better life and/or the possibility of having earnings for themselves or for their families.

\section{Police in Mozambique and Human TrafFicking for Prostitution}

Mozambican governmental officials have recognized the issue of human trafficking since the 1990s, as Mozambique is a signatory country of international agreements and conventions against these crimes. At the same time, however, authorities' inertia with regard to the issue is also clear. This inertia can be understood by considering two important variables: the first is a lack of institutional structure to effectively deal with the issue, an aspect that we will not dwell on; the second relates to the cultural factors (constraints) present in police institutions, which are responsible for a certain indifference to the problem. We will address this issue in the following sections.

The northern region of Mozambique is made up of several ethnic groups, including the five main ones: the Macuas, the Tongas, the Macondes, the Nhanjas and the Swahilis. The Macuas form the largest ethnic 
group in the country. In addition to Mozambique, they can also be found in Tanzania, Malawi, Madagascar and the Seychelles. Nampula province, located in the northern region of the country, is predominantly inhabited by the Macua people. According to the National Research Institute of Mozambique (INE), this province has a population of approximately four million people, of which $98 \%$ belong to the Macua ethnic group.

The social life of the Macua is traditionally linked to certain rites of passage that incorporate, among other teachings, culturally legitimated ways of manifesting sexuality. Men and women, at a certain developmental stage should marry to affirm themselves as insiders within the group. Osório (2013) comments that these rituals aim to counteract fears of community instability if young people, especially women, do not opt to marry. Sexual relationships for Macua women are considered legitimate only in the case of marital relations. This stems from the fear that women who do not opt for marriage may possibly have sexual relations with married men. Not observing these precepts constitutes a rupture of community rules passed down to young Macua women through a ritual called "Mualy."

This ceremony is little known outside of Mozambique and consists of a rite of passage to which teenagers are subjected: men must go through this ritual once and women twice - one time in adolescence and once just before marriage. During this ceremony young people essentially learn what it means to behave properly as a man and as a woman and what their specific roles are. For men, this means becoming aware of his responsibilities related to food production system, and for women, it implies assuming the duties and skills to care for and sexually satisfy their husbands. This skill is acquired from older experienced/knowledgeable women in the family.

Knowledge gained through the Mualy should be assimilated by young people and after passing through the ritual, young people are separated from those whose behaviors are not in line with the Mualy. Those who display transgressive behavior in relation Mualy's teachings are called "Amalapos." Thus, any sexual behavior at odds with the teachings of Mualy is not recognized or respected by the community. In this way, Amalapos are a kind of undesirable outcast, from which all, especially young people, must seek to keep their distance. Among reprehensible behaviors is prostitution, which, regardless of the reasons why it is practiced, is considered abnormal behavior, and the person who sells sex is considered responsible for his/her actions.

Police officers share these traditional cultural values and practices in Mozambique. In general, these professionals see the behavior of female Amalapos as a threat to harmonious living within a community. For this reason, victims trafficked into prostitution are not considered victims. Police authorities may even deny the existence of such a phenomenon. Expressions such as, "we have never heard of women trafficked for prostitution occurring here in Nampula, neither trafficked from here or this being a destination [...]". "We have also never received any complaints related to trafficking of women" represent this perception. Such ignorance, intentional or not, directly interferes with identifying and dealing with this type of crime and delays the promotion of preventive actions.

It is hard to believe that police officers are unaware of this phenomenon, especially in light of the data presented here and the fact that Mozambique is a signatory to the 2000 UN-sponsored Palermo Protocol criminalizing human trafficking, especially that of women and children. The definition of this type of crime in Mozambique's Law No. 6, decreed on July 9, 2008 was fully transposed from the definitions used in the Palermo Protocol. Police also seem to ignore data from the 2014 Attorney General's report, which highlights occurrences of women trafficked for different types of exploitation, including sexual exploitation for prostitution. In this report, the Nampula province is specifically referred to as a place where this type of crime occurs.

This indifference thus seems to stem from the fact that the victims are considered Amalapo. The police belong to the same culture that stigmatizes prostitution and construes female prostitutes as people who compromise the harmonious coexistence of their communities, and therefore do not deserve attention or consideration. Police say in regard to female prostitutes that "they do not respect themselves," implying that they are more concerned with protecting women who behave according to local standards of sexual behavior and that the condition of prostitution is an abnormality, and thus should not be one of their concerns.

One police officer's comment is particularly enlightening: "there are cases where women like to prostitute themselves or do so by their own will; in some cases, it is a bad spirit that enters the woman and induces her to practice this activity." Such a manifestation is profoundly imbedded with the sacred attributes of the Mualy, which makes the victim responsible for her condition as an Amalapo. Other officer commented: "times are different now; before the Mualy taught women to take care of the home and her husband; [today], after the teachings, many girls use these lessons in sexual practices linked to benefits earned from men." The words of another officer clarify this point: "we have received complaints from many prostitutes and it being our professional obligation to attend to citizens' concerns, we welcome them and their demands, and advise them to leave behind this type of life."

This type of attitude denies the problem even though in 2002, 52 children disappeared from the Nampula province - occurrences that gave rise to the first National Debate on Combating Trafficking of 
Human Beings. Following this event, a National Human Rights Plan was approved. However, until 2006, there were no official record of how many people were trafficked for prostitution since no legal provision for such crimes existed. Only in 2008, were the first cases of women trafficked to South Africa officially recognized by Mozambican institutions. In 2009, a specialized government sector dedicated to violence against women was finally created, called the Department of Assistance for Families and Victims of Domestic Violence (Departamento de Atendimento à Família Vítima de Violência Doméstica).

Osório (2013)'s comments are clarifying when he affirms that representations of sexuality play an important role in subjects' experiences and the normative standards that traditionally regulate them. This is perhaps one factor underlying the social intolerance of Mozambicans regarding the sexual behavior of women categorized as Amalapo or prostitutes. It also explains the lack interest of law enforcement authorities in treating the trafficking of women for prostitution as a human rights violation - one that should be prevented and controlled.

\section{Conclusion}

In the $19^{\text {th }}$ century, officials in Europe were concerned about the trafficking of women for prostitution. They focused essentially on preventing the trafficking of white women to African colonies and other continents. During the twentieth century, and especially in the early twenty-first century, concerns about prostitution were placed within a more complex framework of human trafficking connected to attempts of illegal immigration, forced labor, and sexual exploitation.

The African continent has historically been affected by trafficking - from the capture of people to be sold into slavery within the colonial economy since 15th century, to the latest forced migration flows induced by wars, political problems, ethnic persecution and financial hardships. It is in this context, that we can understand the trafficking of Mozambican men and women, but more prominently women, for prostitution.

The failure of the Mozambican authorities to fully implement international agreements, to which the country is a signatory, stems from the country's institutional limitations. These limitations, in turn, are related to the devastating effects of two wars - a war for independence and a civil war - from which the nation is still recovering. On the other hand, it is also linked to the traditional cultural configuration of Mozambican society, which as we presented above, constitute how police in the city of Nampula represent and perceive prostitution and the women involved in these activities.

Mualy's ritual institution gives legitimacy to the sexual practices of Macua women, while legitimizing the stigmatization of those who display Amalapo behavior. Thus, the legal instruments that criminalize the trafficking of women for prostitution do not resonate with local police perceptions of this phenomenon. The officers interviewed for this study largely see Amalapo women as responsible for their own condition since prostitution violate the harmony of social life and threatens families; these types of women, in their view, should have married and prostitution should not exist.

These values, when present in Mozambican policemen's worldview, result in a certain indifference to the problems of human trafficking and prostitution. As a consequence, they can help us understand and explain the failures of governmental actions to curb these activities. Because prostitution is identified as a characteristic of Amalapos means these women are not seen as victims, and the legal resources available to protect victims and prevent and combat these crimes are not applied. Rather, this phenomenon is simply viewed as socially inappropriate behavior. Prostitutes are thought to be responsible for his/her involvement in the activity and its consequences. Thus, while the legal apparatus that corresponds to the national republican State may contemplate a social practice as a crime, and it is recognized as such by international human rights treaties, the behavior of public security and criminal justice authorities, based in traditional values and references, can contribute to the permanence and reproduction of harmful criminal activities, such as human trafficking.

\section{References Références Referencias}

1. Adepoju, A. (2000). Issues and recent trends in international migration in Sub-Saharan Africa. International Social Science Journal, 52(165), 383-394. https://doi.org/10.1111/1468-2451.00267.

2. Aderinto, S. (2015). Journey to work: Transnational prostitution in colonial British West Africa. Journal of the History of Sexuality, 24(1), 99-124. https://doi.org/10.7560/JHS24105.

3. Alexandre, V. (2008). O império africano: Séculos XIX e XX. Lisboa: Colibri.

4. Alós, A. P. (2011). Memória cultural e imaginário pós-colonial: O lugar de Lília Momplé na literatura moçambicana. Caligrama: Revista de Estudos Românicos, 16(1), 137-158. http://dx.doi.org/10. 17851/2238-3824.16.1.137-158.

5. Arnfred, S. (2002). Conceptions of gender in colonial and post-colonial discourses: The case of Mozambique. CODESRIA 10th General Assembly on Africa in the New Millennium, Kampala, Uganda, 8-12.

6. Ausserer, C. (2011). Controle em nome da proteção: análise do discurso de tráfico de pessoas como problema de migração. REHMU: Revista Interdisciplinar da Mobilidade Humana, 19(37), 107-123. 
7. Bales, K.; Friman, H. R. (2002). Disposable people: new slavery in the global economy. Labour, 49, 338.

8. Bank, C. M. van der. (2010). Globalisation and human rights: Some implications for the African content and government. World Journal of Entrepreneurship, Management and Sustainable Development, 6(3), 181-191. https://doi.org/10.11 08/20425961201000014.

9. Barros, L. ; Lahlou, M. ; Escoffier, C. ; Pumares, P. ; Ruspini, P. (2002) L'immigration irrégulière subsaharienne à travers et vers le Maroc. Genève: Bureau International du Travail (Cahiers de Migrations Internationales, 54F).

10. Bullough, V. L.; Bullough, B. (1987). Women and prostitution: a social history. New York: Prometheus Books.

11. Carling, J. (2007). Unauthorized migration from Africa to Spain. International Migration, 45(4), 3-37. https://doi.org/10.1111/j.1468-2435.2007.00418.x.

12. Cohen, S. (1992). The evolution of women's asylums since 1500: From refuges for ex-prostitutes to shelters for battered women. New York: Oxford University Press.

13. Collier, P.; hoeffler, A. (1998). On economic causes of Civil War. Oxford Economic Papers, 50(4), 563573. https://doi.org/10.1093/oep/50.4.563.

14. Collier, P.; sambanis, N. (2005). Understanding Civil War: Evidence and analysis (Vol. 1 Africa). Washington, DC: World Bank.

15. Connelly, L.; sanders, T. (2016). Prostitution/Sex Work. The Wiley Blackwell Encyclopedia of Gender and Sexuality Studies. Hoboken, NJ: John Wiley \& Sons. https://doi.org/10.1002/9781118663219.wbeg ss362.

16. Dias, A. L.; lucio, J.; coelho, T. D. (2015). "Corrupção e pobreza em África: Os legados coloniais em perspectiva comparada". Revista do Serviço Público, 66 (3), 395-424.

17. Feliciano, J. F. (1998). Antropologia económica dos Thonga do sul de Moçambique. Maputo: Arquivo histórico de Moçambique.

18. Fry, P. (2000). O Espírito Santo contra o feitiço e os espíritos revoltados: "civilização" e "tradição" em Moçambique. Mana, 6(2), 65-95. http://dx.doi.org/ 10.1590/S0104-93132000000200003.

19. Groes-green, C. (2011). The bling scandal: Transforming young femininities in Mozambique. Young - Nordic Journal of Youth Research, 19(3), 291-312. https://doi.org/10.1177/110330881101900 303.

20. Hamela, E. (2011). Os custos das cadeias para a sociedade: Que contribuição ao desenvo/vimento de Moçambique? Maputo: Publifix.

21. Lagunas, D. (2010). El poder del dinero y el poder del sexo: Antropología del turismo sexual. Perfiles Latinoamericanos, 18(36), 71-19.
22. Langa, A. (1984). Questões cristãs à religião tradicional africana, Moçambique. Braga: Editorial Franciscana.

23. Leite, J. P. (1999). A Guerra do Caju e as Relações Moçambique-Índia na Época Pós-Colonial. Lusotopie, 295-332. https://www.repository.utl.pt/ bitstream/10400.5/1125/1/ DocTrab_57.pdf.

24. Lopes, F. F. (1972). Missões franciscanas em Moçambique, 1898-1970. Braga: Editorial Franciscana.

25. Meneses, M. P. (2008). Mulheres insubmissas? Mudanças e conflitos no norte de Moçambique. Ex aequo, 17, 71-87. http://www.scielo.mec.pt/pdf/ aeq/n17/n17a05.pdf.

26. Muianga, B. S. (2009). Risco e saúde no contexto do $\mathrm{VIH} /$ sida: O caso da prostituição na Baixa da Cidade de Maputo. Tese de Doutorado, Instituto Universitário de Lisboa, Portugal.

27. Oit - Organização Internacional Do Trabalho. (2006). Secretaria Internacional do Trabalho. Tráfico de pessoas para fins de exploração sexual. Brasília, DF. 80 p. Recuperado em 02 novembro 2018, de https://www.ilo.org/wcmsp5/groups/public/--americas/---ro-lima/---ilo-brasilia/documents/ publication/wcms 233892.pdf.

28. Osório, C. (2013). Identidades de gênero e identidades sexuais no contexto dos ritos de iniciação no Centro e Norte de Moçambique. Outras Vozes, 43-44. http://www.wlsa.org.mz/wp-content/ uploads/2013/12/ldentidades ritos.pdf.

29. Pateman, C. (2016). Sexual contract. The Wiley Blackwell Encyclopedia of Gender and Sexuality Studies. https://doi.org/10.1002/9781118663219.wb egss 468.

30. Pereira, Z. (2000). Os jesuítas em Moçambique: Aspectos da acção missionária portuguesa em contexto colonial (1941-1974). Lusotopie, 7(7), 81-105.

31. Pinho, O. S. de A. (2015). O destino das mulheres e de sua carne: Regulação de gênero e o Estado em Moçambique. Cadernos Pagu, 45, 157-179. http://dx.doi.org/10.1590/18094449201500450157.

32. Raimi, L. (2012). Faith-based advocacy as a tool for mitigating human trafficking in Nigeria. Humanomics, 28(4), 297-310. https://doi.org/10.11 $08 / 08288661211277515$.

33. Bila, A. (Coord.). (2014). Tráfico de pessoas em Moçambique, em particular, de crianças. Maputo, República de Moçambique. Accessed on November 7, 2018 from <https://mozambique. savethechildren.net/sites/mozambique.savethechild ren.net/files/Manual\%20Trafico2.pdf $>$.

34. Roby, J. L. (2005). Women and children in the global sex trade: toward more effective policy. International Social Work, 48(2), 136-147. https://doi. org/10.1177/0020872805050206. 
35. Sanders, T.; o'neill, M.; pitcher, J. (2017). Prostitution: sex work, policy \& politics. Thousand Oaks, CA: SAGE.

36. Statistic Brain Research Institute. Human Trafficking - Mozambique. Accessed on October 20, 2018 from $\quad<$ https://www.statisticbrain.com/humantrafficking-mozambique $>$.

37. Tamale, S. (2006). Eroticism, sensuality and "women's secrets" among the Baganda. IDS Bulletin, 37(5), 89-97. https://doi.org/10.1111/j.17595436.2006.tb00308.x.

38. Thapisa, A. P. N. (2000). The impact of globalisation on Africa. Library Management, 21(4), 170-178. https://doi.org/10.1108/01435120010693988.

39. UNICEF. (2012). Relatório anual sobre o tráfico de mulheres e crianças em Moçambique. Accessed on November 12, 2018 from < https://www.unicef.org/ sowc2012/>. 